\title{
Relating landscape development intensity to coral reef condition in the watersheds of St. Croix, US Virgin Islands
}

\author{
L. M. Oliver*, J. C. Lehrter, W. S. Fisher \\ USEPA, Office of Research and Development, National Health and Environmental Effects Research Laboratory, \\ Gulf Ecology Division, 1 Sabine Island Drive, Gulf Breeze, Florida 32561, USA
}

\begin{abstract}
Land-based sources of pollution are a major threat to the health of coral reefs. We report, for the first time, a study that relates coral reef condition to human modifications of the landscape. Stony coral community richness, cover, colony size, and density were assessed along with 3-dimensional coral cover in the near-shore waters of St. Croix, US Virgin Islands, in 2006 and 2007. Land use/land cover data (LULC, $2.4 \mathrm{~m}$ resolution) and a landscape development intensity (LDI) index, an indicator of human activity calculated from the LULC data, were used to explore relationships with coral indicators. The LDI index was more robust than other indicators of human activity, exhibiting negative correlations with stony coral colony density, taxa richness, colony size, and total coral cover. High variability observed in coral density and taxa richness was better explained when percent natural land and average coral station depth were considered along with the LDI index. Percent impervious surface in the watershed was negatively correlated with 1 coral condition indicator, total coral cover. The LDI index is an effective landscape indicator of human impact on St. Croix corals, highlighting the link between land-based human activity and marine ecosystems. Further development of this tool will aid in land use planning and prioritization of conservation efforts.
\end{abstract}

KEY WORDS: Coral reef condition - Coastal watersheds · Land-cover/land-use · Landscape development intensity (LDI) index

\section{INTRODUCTION}

Coral reefs are productive and diverse ecosystems that provide valuable ecological services such as harvestable fish, a beautiful seascape that attracts tourists, and protection of vulnerable shorelines from storms and wave action (Moberg \& Folke 1999). Protection and restoration of coral reef ecosystems are fundamental management goals for regions of the world where corals are found. However, sustainable coral reef management is hindered, at least in part, by uncertainty surrounding the impacts to coral reefs of the many and varied human-generated stressors (Richmond 1993, Hughes \& Connell 1999, Downs et al. 2005). Coral reef ecosystems may be impacted by local pressures such as landscape development (Dubinsky \& Stambler 1996, Burke \& Maidens 2004, Fabricius 2005), by regional pressures such as over-harvesting of fishery stocks (Valentine \& Heck 2005), and by global pres- sures such as rising sea surface temperatures and ocean acidification stemming from increased atmospheric $\mathrm{CO}_{2}$ (Wilkinson 1996, Hoegh-Guldberg et al. 2007). The variability and interaction of these stressors can confound management strategies for conservation and restoration of coral reef ecosystems. Moreover, effects of local watershed stressors may be masked and difficult to document.

Increases in terrigenous pollutants entering the ocean result from land use changes in coastal and inland watershed landscapes. Clearing land, creating impervious surfaces, and applying fertilizers, herbicides, and pesticides can act in concert to accelerate terrestrial runoff of sediments and associated chemical contaminants known to cause decline in coral ecosystems (Wolanski et al. 2004, Warne et al. 2005, Richmond et al. 2007). Physical smothering and mortality of reef-building scleractinian (stony) corals occurs with prolonged exposure to high levels of sediment. Sediment trans- 
ported to reefs may inhibit stony coral photosynthesis directly by attenuating light (Rogers 1979), or indirectly when energy is diverted to mucus production to slough sediment off coral surfaces (Riegl \& Branch 1995). Negative consequences for corals exposed to sediments include loss of cover (Cortés \& Risk 1985), impaired fertilization (Gilmour 1999), decreased larval settlement and survivorship (Babcock \& Smith 2000), reduced growth (Dodge et al. 1974, Miller \& Cruise 1995), and altered community structure (Loya 1976, for review see Rogers 1990, Fabricius 2005). Despite recognition of these problems, protection of corals from watershed pollution has been limited (Richmond et al. 2007).

An obstacle to effective management at local scales is the lack of quantitative information that links coral condition to human activities on land. This requires both coral condition and human activity indicators. Stony coral indicators are highly valued for coral reef management because stony corals form the permanent infrastructure of a coral reef and provide habitat and nursery grounds for nearly all reef inhabitants (Dahl 1973, Fisher 2007). However, to be useful for relating reef condition to human activity, coral condition indicators must also be sensitive to anthropogenic disturbance over global and regional factors that affect coral condition. This requires testing candidate indicators at sites located across a human activity gradient (Fore et al. 2008). A recent study in St. Croix, US Virgin Islands, found that measurements of stony coral size, taxa richness, and colony density (among others) were sensitive to distance from an active industrial area (Fisher et al. 2008). Consequently, these measurements were candidates for investigating relationships between reef condition and human activities in the watershed.

Although development of indicators for human activity has been challenging (Mack 2006), a landscape development intensity (LDI) index, calculated from land-use/land-cover (LULC) data, has shown great promise for quantifying human disturbance (Brown \& Vivas 2005). The LDI index has been successfully related to pollutant loads (Brown \& Vivas 2005), to the ecological condition of wetlands in both the midwest (Mack 2006, 2007) and southeast USA (Brown \& Vivas 2005, Reiss \& Brown 2007), and has been adopted into condition assessment protocols for aquatic ecosystems by several US states. LDI represents the cumulative anthropogenic impact in terms of nonrenewable energy to a landscape unit; in this case, a watershed. The basis for the LDI lies in spatially explicit, highresolution LULC data that offer valuable information for landscape ecology studies (Wu 2006).

Here, the LDI was applied in a novel context that explores potential extension of landscape ecology methods to the seascape. In this exploratory comparison, stony coral condition was related to watershed
LULC and LDI values. We also compared the capacity of other potential human activity indicators to predict coral reef condition using multivariate analysis. If significant relationships between human activity and coral condition were found, the expectation was that watersheds with greater human impact would be associated with reduced coral reef condition. The methods and relationships discovered have potential use for the development of water quality standards based on coral condition (i.e. biological criteria, Fore et al. 2008, 2009) and for local land-use zoning, planning, and permitting as pertains to the conservation and restoration of sustainable coral reef ecosystems.

\section{MATERIALS AND METHODS}

Coral condition data. Coral survey data were collected during 2 surveys in the coastal waters of St. Croix (US Virgin Islands) using the US Environmental Protection Agency's (USEPA) stony coral rapid bio-assessment protocol (Fisher 2007). Stations were selected for the 2006 survey in 4 coastal zones, viz. 3 zones near centers of human activity and 1 zone with minimal human activity, to test the responsiveness of coral indicators (Fig. 1, Fisher et al. 2008). Stations were selected for targeted sampling following snorkel reconnaissance for the best available habitat (i.e. highest coral cover) at approximately constant intervals from predetermined locations. In the second survey (2007), stations were selected randomly from 'coral and hardbottom' areas identified on benthic habitat maps (Rohmann et al. 2005, NOAA; http://ccma.nos.noaa.gov/ecosystems/ coralreef/usvi_pr_mapping.html). Sites were selected using a probabilistic approach to avoid redundancy yet allow spatial extrapolation of results to the entire region (Hughes et al. 2000, USEPA 2008). Site selection was confined to coral and hardbottom areas within $1.5 \mathrm{~km}$ of shore and $<12 \mathrm{~m}$ depth (Fig. 1).

One transect was surveyed at each station. Survey transects were established by placing a tripod on the substrate which held an upright pole in place, and a $2 \mathrm{~m}$ wide annulus (radial belt) was surveyed 3 to $5 \mathrm{~m}$ from the pole. Data were recorded from either a full annulus $\left(360^{\circ}\right.$; transect area $\left.=50.2 \mathrm{~m}^{2}\right)$ or a half annulus $\left(180^{\circ}\right.$; transect area $\left.=25.1 \mathrm{~m}^{2}\right)$ if colony density was very high. Data for full-annulus transects were collected in half-annulus segments and averaged to obtain a single station value. All stony corals (order Scleractinia) described by Humann \& Deloach (2002) and 1 reef-building hydrocoral (Millepora complanata) were included in the survey. Because goals of the 2 surveys did not include coral recruitment, only colonies $>10 \mathrm{~cm}$ in diameter were documented. Coral species, colony dimensions, and approximate \% live tissue were 


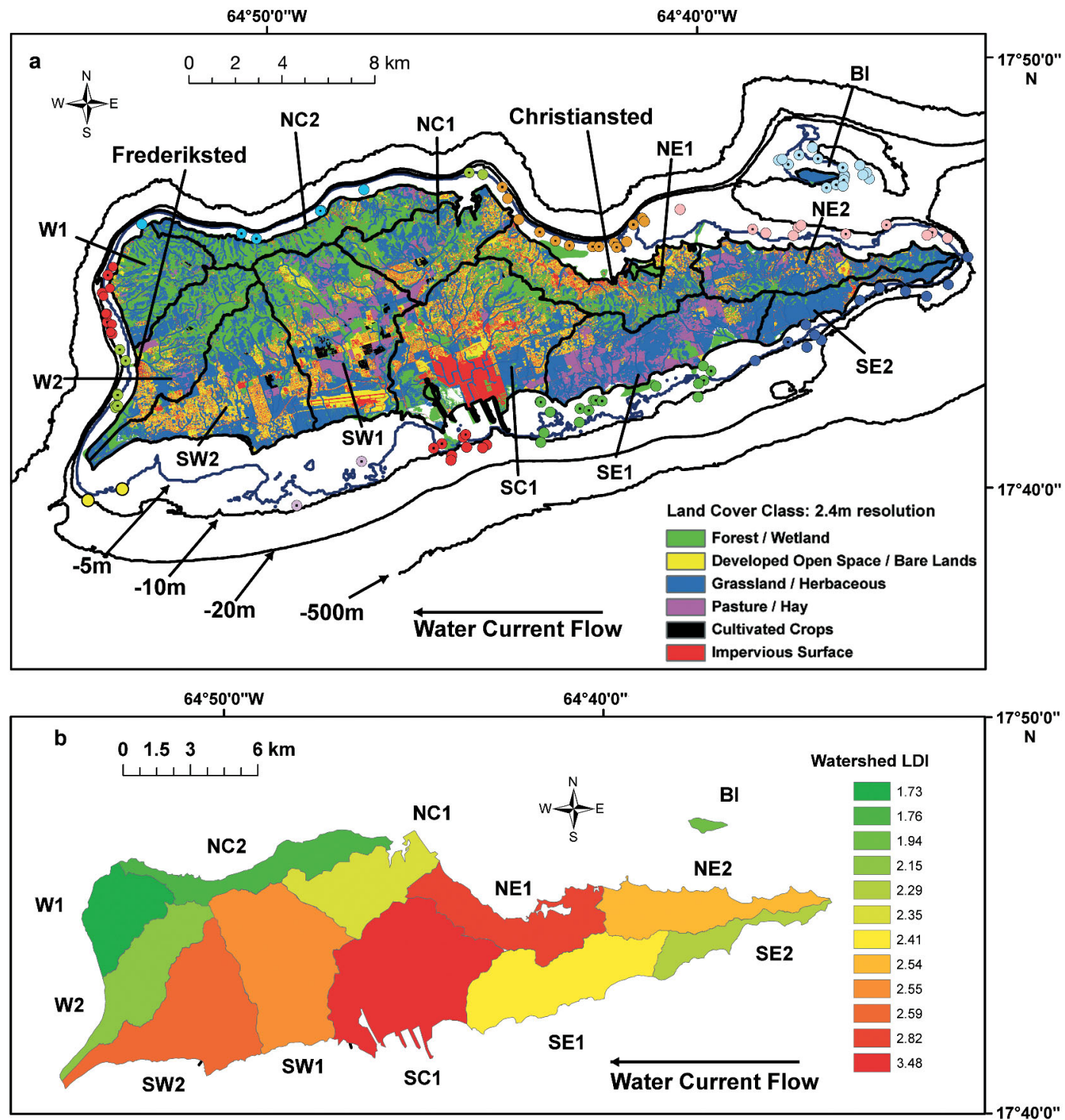

Fig. 1. (A) St. Croix watersheds and associated coral stations from 2006 (circles with dots) and 2007 (circles). Clusters of stations that share a common color (colors are not related to those used to indicate land use) were associated with the adjacent watershed for evaluating relationships between watershed metrics of human disturbance and coral condition. Land use/land cover used in the analysis is shown at $2.4 \mathrm{~m}$ resolution. (B) Watershed landscape development intensity (LDI) values shown on a greenyellow-red continuum, where green indicates the lowest human disturbance and red indicates the highest. Watershed abbreviations: BI: Buck Island; NC: North Central: NE: Northeast; SC: South Central; SE: Southeast; SW: Southwest; W: West

recorded. Coral size was calculated from measured dimensions as 3-dimensional (3D) colony surface area (SA) rather than traditional projected (planar) 2-dimensional SA, to capture habitat values (Fisher 2007). Three-dimensional coral colony SA was calculated as 3D area $=x \pi r^{2}$, where $x=1,2,3$, or 4 depending on species and typical topographic complexity of colonies; flat colonies were assigned a '1' (including Agaricia agaricites, A. fragilis, Meandrina meandrites, Mycetophylia ferox, and M. lamarckiana); hemispherical colonies were assigned a '2' (brain and massive corals including Diploria spp., Montastrea cavernosa, $M$. faveolata, M. franksii, and Porites astreoides); dome- shaped, lobed, plate, and finger corals were assigned a '3' (Agaricia tenuifolia, Dichocoenia stokesii, Montastrea annularis, and Porites spp.); and highly branched corals of the genus Acropora were assigned a '4.' This approach to SA estimation was adapted from Dahl (1973) and Acala \& Vogt (1997), who also used surface index adjustments to estimate 3D SA. Dendrogyra cylindricus was the exception, for which a geometric formula for a cylinder was used to estimate SA ([2 $\pi \mathrm{r} \mathrm{h}]$ $\left.+\left[\pi r^{2}\right]\right)$. Live colony SA was calculated by multiplying colony size $\times$ decimal \% live tissue. Coral size and condition metrics were calculated and standardized per $\mathrm{m}^{2}$ of sea floor (Table 1). 
Table 1. Coral condition indicators and calculations, based on the USEPA's Stony Coral Rapid Bio-Assessment Protocol (Fisher 2007). Indicators of individual coral colony size and coral cover $\left({ }^{*}\right)$ were calculated based on 3-dimensional (3D) surface area (SA) measurements. LT: Live tissue

\begin{tabular}{|ll|}
\hline Coral indicator & Calculation \\
\hline Coral density & $\begin{array}{c}\text { No. of stony coral colonies } / \mathrm{m}^{2} \\
\text { sea floor }\end{array}$ \\
Average \% live tissue & $\Sigma \%$ LT/colonies \\
Taxa richness & No. of taxa $/ \mathrm{m}^{2}$ sea floor \\
Average colony SA & $\Sigma$ 3D SA $/$ no. of colonies ${ }^{-1}$ \\
Average live colony SA* & $\Sigma$ live 3D SA/no. of colonies \\
3D total coral cover* & $\Sigma \mathrm{SA} / \mathrm{m}^{2}$ sea floor \\
3D live coral cover* & $\Sigma$ live SA $/ \mathrm{m}^{2}$ sea floor \\
\hline
\end{tabular}

Landscape data. Geospatial data processing and analyses were conducted in ArcGIS (Environmental Systems Resource Institute, ArcMap 9.2). Eleven St. Croix watersheds were delineated with the Arc Hydro tool in ArcMap using digital geospatial data from the National Elevation Dataset (NED; http://nhd.usgs.gov) and National Hydrography Dataset (NHD; http://ned. usgs.gov). Buck Island was included as a watershed for a total of 12 spatial landscape units. St. Croix watershed shapefiles were used to estimate simple landscape watershed metrics such as watershed areal extent, mean watershed elevation data from the NED, total length of streams from the NHD, and human population data (Burke \& Maidens 2004). Watershed shapefiles were also used to clip LULC data from 2007 produced by NOAA Coastal Change Analysis Program (www.csc.noaa.gov/digitalcoast/data/ccaphighres/ download.html), and to generate percentage of each land cover type including impervious surface and natural land (undeveloped wetlands, forests, and open space). Watershed LDI values were calculated using the method of Brown \& Vivas (2005); each land use category was assigned an LDI coefficient based on cumulative, nonrenewable energy input received by each land use type (Table 2). An area-weighted LDI index was then calculated for each watershed as follows: $\mathrm{LDI}_{\text {watershed }}=\left(\Sigma \% \mathrm{LU}_{i} \times \mathrm{LDI}_{i}\right) / 100$, where $\% \mathrm{LU}_{i}=$ percent watershed land area in land use $i$, and $\mathrm{LDI}_{i}=\mathrm{LDI}$ coefficient for land use $i$ (Fig. 1, Table 2).

Correlation and multivariate analyses. For purposes of relating watershed metrics of human activity to coral condition, sites from both the 2006 and 2007 coral condition surveys were assigned to watersheds based on their proximity to the watershed coastlines. Due to a strong westward ocean current, discharges entering to the north or south coasts will tend to transport sediments and anthropogenic contaminants offshore and to the west (Hubbard 1986); therefore, in 7 cases where stations fell close to a boundary, values were assigned to the eastward watershed (Fig. 1). The average depth of the
Table 2. Land use/land cover (LULC) classifications from $2.4 \mathrm{~m}$ resolution land use raster dataset (NOAA 2009). Landscape development intensity (LDI) coefficients (Brown \& Vivas 2005) were assigned to each class. Braces indicate the LULC and LDI that were aggregated to calculate the percentage of St. Croix's landscape (\% of landscape) represented by each unique LDI

\begin{tabular}{|lcc|}
\hline NOAA LULC class & $\begin{array}{c}\text { LDI } \\
\text { coefficient }\end{array}$ & $\begin{array}{c}\text { \% of } \\
\text { landscape }\end{array}$ \\
\hline Impervious surface & 8.28 & 11.7 \\
Cultivated crops & 4.42 & 0.6 \\
Pasture/hay & 3.03 & 6.4 \\
Grassland/herbaceous & 2.06 \\
Scrub/shrub & 2.06 & 37.5 \\
Bare land & 1.85 \\
Developed, open space & 1.85 \\
Deciduous forest & 1.00 \\
Evergreen forest & 1.00 \\
Palustrine forested wetland & 1.00 \\
Palustrine scrub/shrub wetland & 1.00 \\
Palustrine emergent wetland & 1.00 \\
Estuarine forested wetland & 1.00 \\
Estuarine scrub/shrub wetland & 1.00 \\
Estuarine emergent wetland & 1.00 \\
Unconsolidated shore & 1.00 \\
Open water & 1.00
\end{tabular}

coral condition stations assigned to each watershed was calculated to assess how variations in sample depths impacted coral condition variability. Similarly, coral condition variability by watershed was evaluated in relation to the average distance of the stations to the midpoint of the watershed shoreline. This was evaluated to assess how distance from land impacted coral condition.

Station averages were generated using SAS software (SAS Institute), for coral colony density, percent live tissue, coral colony SA and live colony SA, and totals were tallied for taxa richness, 3D total coral cover, and 3D live coral cover. From these station-level coral indicators, median values were generated from sites assigned to each watershed. Pearson correlation analysis was conducted post hoc to explore relationships between watershedlevel median coral indicators and watershed LDI indices, and between coral indicators and watershed percent impervious surface values. Given the exploratory nature of these analyses, we adopted $\mathrm{p}<0.10$ as the significance criterion for these correlations. Linear regression analyses were conducted to examine which of the independent variables (Table 3) explained most of the variability. Correlations among independent variables were assessed by examining Pearson correlation coefficients. Stepwise multiple regression models were developed (S-Plus, Insightful) after screening variables with high correlations to one another to select the most meaningful variables. Selected regression models were evaluated to determine how much of the coral condition variability could be described by these simple landscape metrics. 
Table 3. St. Croix watershed characteristics: number of coral survey stations from each year and total number used in analysis, average depth of coral stations, average percent impervious surface and natural land, average elevation, total area, human population density, total stream length, and landscape development intensity (LDI) index. nd: no data available. Watershed abbreviations as in Fig. 1

\begin{tabular}{|c|c|c|c|c|c|c|c|c|c|c|c|}
\hline $\begin{array}{l}\text { Water- } \\
\text { shed }\end{array}$ & $\begin{array}{l}\text { No. of } \\
2006\end{array}$ & $\begin{array}{l}\text { coral } \\
2007\end{array}$ & $\begin{array}{l}\text { stations } \\
\text { Total }\end{array}$ & $\begin{array}{l}\text { Station } \\
\text { depth } \\
\text { (m) }\end{array}$ & $\begin{array}{c}\% \\
\text { imperv. } \\
\text { surface }\end{array}$ & $\begin{array}{c}\% \\
\text { natural } \\
\text { land }\end{array}$ & $\begin{array}{l}\text { Elevation } \\
\text { (m) }\end{array}$ & $\begin{array}{l}\text { Area } \\
\left(\mathrm{km}^{2}\right)\end{array}$ & $\begin{array}{l}\text { Human popu- } \\
\text { lation density } \\
\left(\text { no. } \mathrm{km}^{-2}\right)\end{array}$ & $\begin{array}{l}\text { Total stream } \\
\text { length }(\mathrm{km})\end{array}$ & $\begin{array}{l}\text { LDI } \\
\text { index }\end{array}$ \\
\hline W1 & 4 & 6 & 10 & 8.0 & 3.6 & 53.2 & 111.2 & 12.02 & 24.5 & 16.85 & 1.73 \\
\hline W2 & 8 & 0 & 8 & 9.0 & 8.1 & 41.0 & 84.4 & 16.55 & 334.3 & 18.50 & 2.15 \\
\hline SW2 & 0 & 2 & 2 & 5.0 & 10.3 & 30.4 & 52.5 & 27.72 & 136.9 & 32.75 & 2.59 \\
\hline SW1 & 2 & 0 & 2 & 6.2 & 12.3 & 20.5 & 60.9 & 31.82 & 227.1 & 32.36 & 2.55 \\
\hline SC1 & 5 & 5 & 10 & 6.3 & 27.5 & 24.9 & 44.9 & 36.36 & 709.8 & 40.51 & 3.48 \\
\hline SE1 & 11 & 8 & 19 & 5.9 & 3.6 & 10.4 & 46.7 & 22.89 & 162.4 & 29.16 & 2.41 \\
\hline SE2 & 1 & 11 & 12 & 7.9 & 5.1 & 8.2 & 53.5 & 7.21 & 11.4 & 3.90 & 2.29 \\
\hline NE2 & 5 & 6 & 11 & 7.5 & 9.1 & 13.8 & 51.7 & 15.43 & 40.3 & 9.84 & 2.54 \\
\hline NE1 & 10 & 4 & 14 & 7.6 & 18.6 & 33.7 & 51.2 & 16.92 & 201.6 & 11.05 & 2.82 \\
\hline $\mathrm{NC1}$ & 1 & 1 & 2 & 11.4 & 10.4 & 38.6 & 68.1 & 15.95 & 201.4 & 20.63 & 2.35 \\
\hline NC2 & 4 & 2 & 6 & 8.7 & 4.8 & 57.6 & 89.9 & 13.31 & 17.9 & 9.53 & 1.76 \\
\hline BI & 10 & 7 & 17 & 8.7 & 0 & 11.7 & nd & 0.71 & 0 & 0 & 1.94 \\
\hline
\end{tabular}

\section{RESULTS}

From 113 stations surveyed in 2006 and 2007, a total of 5791 coral colonies were examined and measured. The number of survey stations associated with each watershed ranged from 0 to 11 in separate years and from 2 to 19 for combined years (Table 3). All except 3 of the watersheds had at least 6 assigned coral survey sites (Table 3, Fig. 1A). Average depth of watershed stations ranged from 5.0 to $11.4 \mathrm{~m}$, and average watershed area ranged from 0.71 to $36.36 \mathrm{~km}^{2}$ (Table 3). Of 39 unique coral taxa, 8 species comprised 88 and $87 \%$, respectively, of total and live 3D coral cover across all stations: (in descending order) Montastrea annularis, M. faveolata, M. cavernosa, Diploria strigosa, Siderastrea siderea, Porites porites, Acropora palmata, and P. astreoides. Median values for targeted coral indicators were consistently high for both west coast watersheds (W1 and W2), and in most cases for $\mathrm{NC} 2$ and Buck Island (BI; Figs. 2 \& 3). Of the suite of coral indicators, median percent live tissue varied the least, ranging from 53 to $71 \%$ (Fig. 2B). Buck Island stations had the highest medians for average colony surface area and average live colony surface area, indicating the large size of corals observed there as well as relatively large amounts of live tissue per colony (Fig. 3A,B). West coast watersheds and SW1 also had large median coral colony size, and when summed, W1, W2, BI, and NC2 had highest 3D total coral cover and 3D live coral cover (Fig. 3). Watersheds along the south
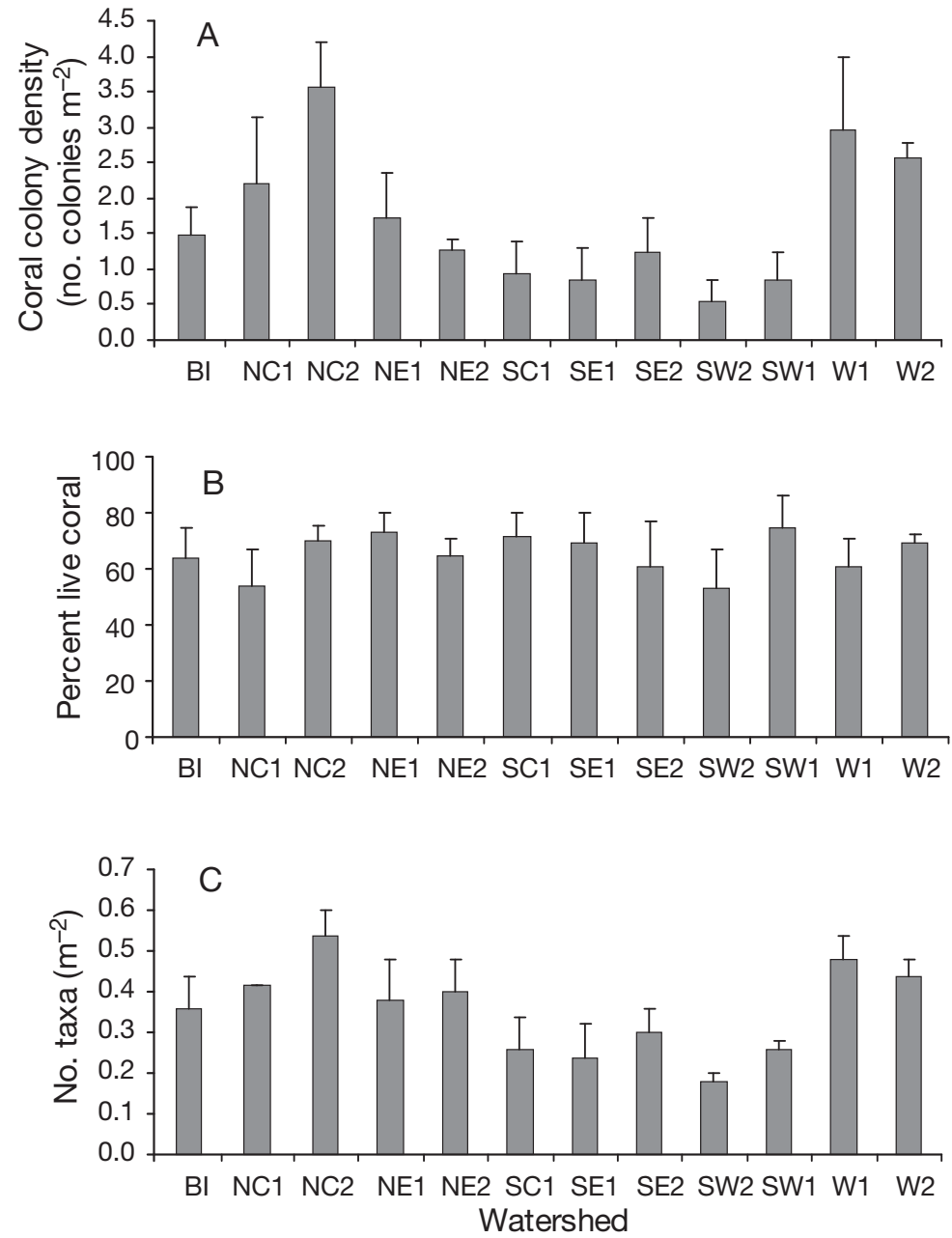

Fig. 2. Median values for (A) coral colony density, (B) percent live coral, and (C) taxa richness, for grouped 2006 and 2007 St. Croix stony coral survey stations assigned to each of 12 watersheds. Error bars are the median absolute deviations. Watershed abbreviations as in Fig. 1 

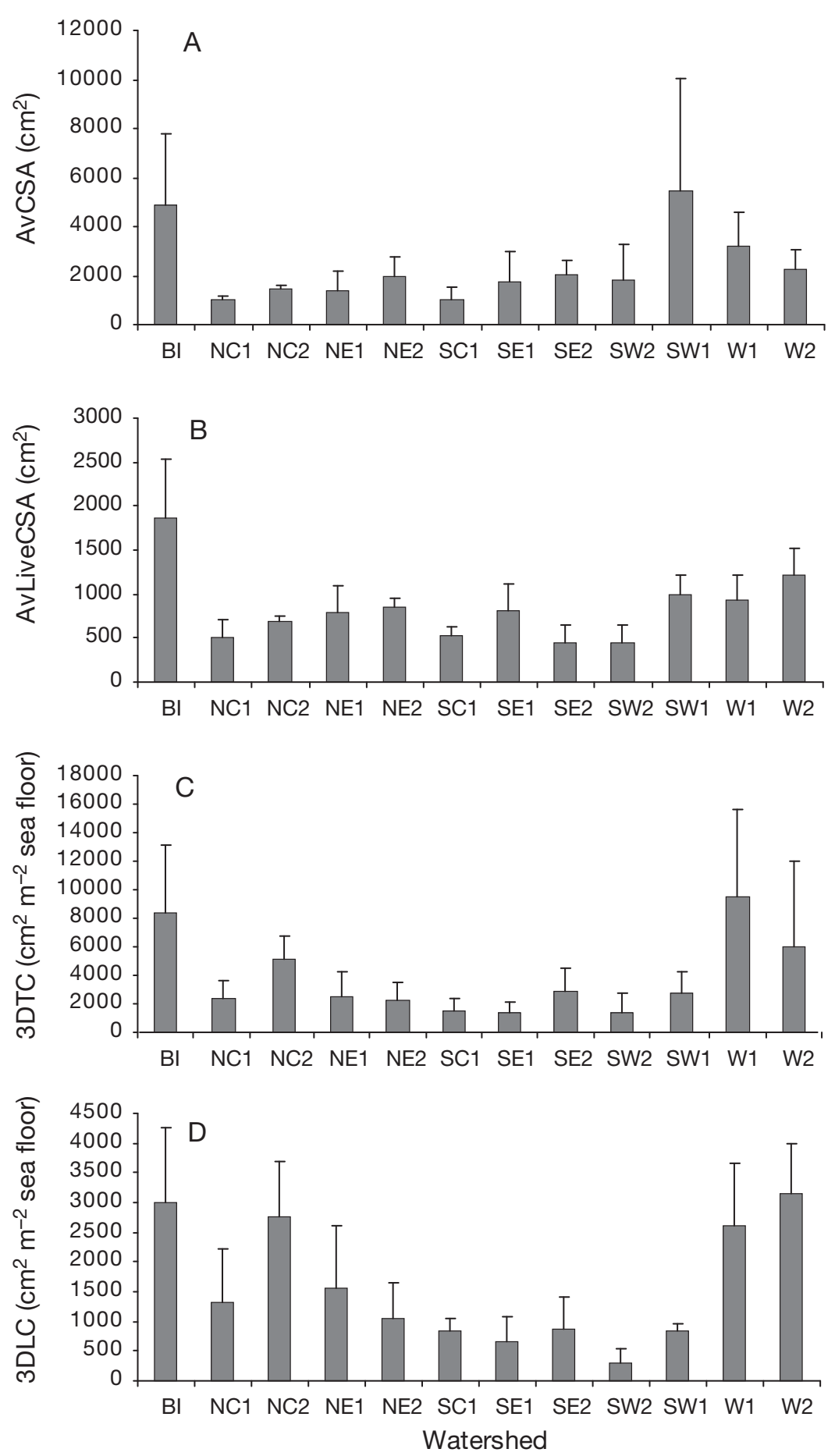

Fig. 3. Median values for (A) average colony surface area (AvCSA), (B) average live colony surface area (AvLiveCSA), (C) 3D total coral cover (3DTC), and (D) 3D live coral cover (3DLC), for grouped 2006 and 2007 St. Croix stony coral survey stations assigned to each of 12 watersheds. Error bars are the median absolute deviations. Watershed abbreviations as in Fig. 1

shore (SW1, SW2, SC1, SE1, and SE2) had the lowest median colony densities and taxa richness (Fig. 2), and except for a high median colony size for SW1, also had smaller colonies and reduced reef area (Fig. 3).
Highest LDI values were calculated for south shore watersheds (in descending order) SC1, SW1, SW2, and north shore watersheds NE1 and NE2 (Table 3, Fig. 1B). While NE1 and NE2 had similar LDIs, they differed in land use, with NE1 having $18.6 \%$ impervious surface (including the city of Christiansted) and NE2 only 9.1\%. Western watersheds also had relatively low LDIs that were closer in agreement than their respective proportion of impervious surface values (Table 3); W2 contains the city of Frederiksted, which is reflected in the higher proportion of impervious surface compared to W1 (Table 3, Fig. 1). Areaweighted LDI for St. Croix $=2.5$, and watershed values ranged from 1.73 to 3.48 (Table 3). The highest LDI coefficient is that for impervious surface, which amounted to $11.3 \%$ of island-wide land area and contributed most to high LDI values for south shore watersheds, and for W2 and NE1. Of 2 agriculture land use classes applicable to St. Croix, high-intensity crop cultivation accounted for $0.6 \%$ of total land, while pasture use and hay production comprised $6.4 \%$ (Table 2). On a watershed level, pasture and hay contributed $25.8 \%$ of land use in SE1, $13.7 \%$ in SW1, $8.1 \%$ in NE2, and $5.2 \%$ in NC1 (Fig. 1). Natural lands with lowest LDI coefficients, including forests and wetlands, were in greatest proportion in NC2, W1, W2, NC1, and NE1, where they comprised $34 \%$ to $58 \%$ of land (Table 3 ).

Significant negative correlations were found between watershed LDI scores and coral condition data (2006 and 2007 combined) for stony coral density, taxa richness, average colony surface area, average live colony surface area, 3D total coral cover, and 3D live coral cover (Fig. 4). Removal of a single outlying watershed (Fig. 4C) improved the strength of the relationship for average colony surface area. Some of these relationships were found to be significant for 2006 and 2007 data analyzed separately (results not shown). The only coral indicator that showed a positive correlation with watershed LDI was average percent live tissue. Watershed percent impervious surface correlated negatively only with 3D coral cover for combined-year data $(r=-0.57, p=0.055)$ and with both 3D total coral cover and 3D live total coral cover for 2006 data $(r=-0.59, p=0.058 ; r=-0.55$, $\mathrm{p}=0.078$, respectively). Within the suite of coral indi- 

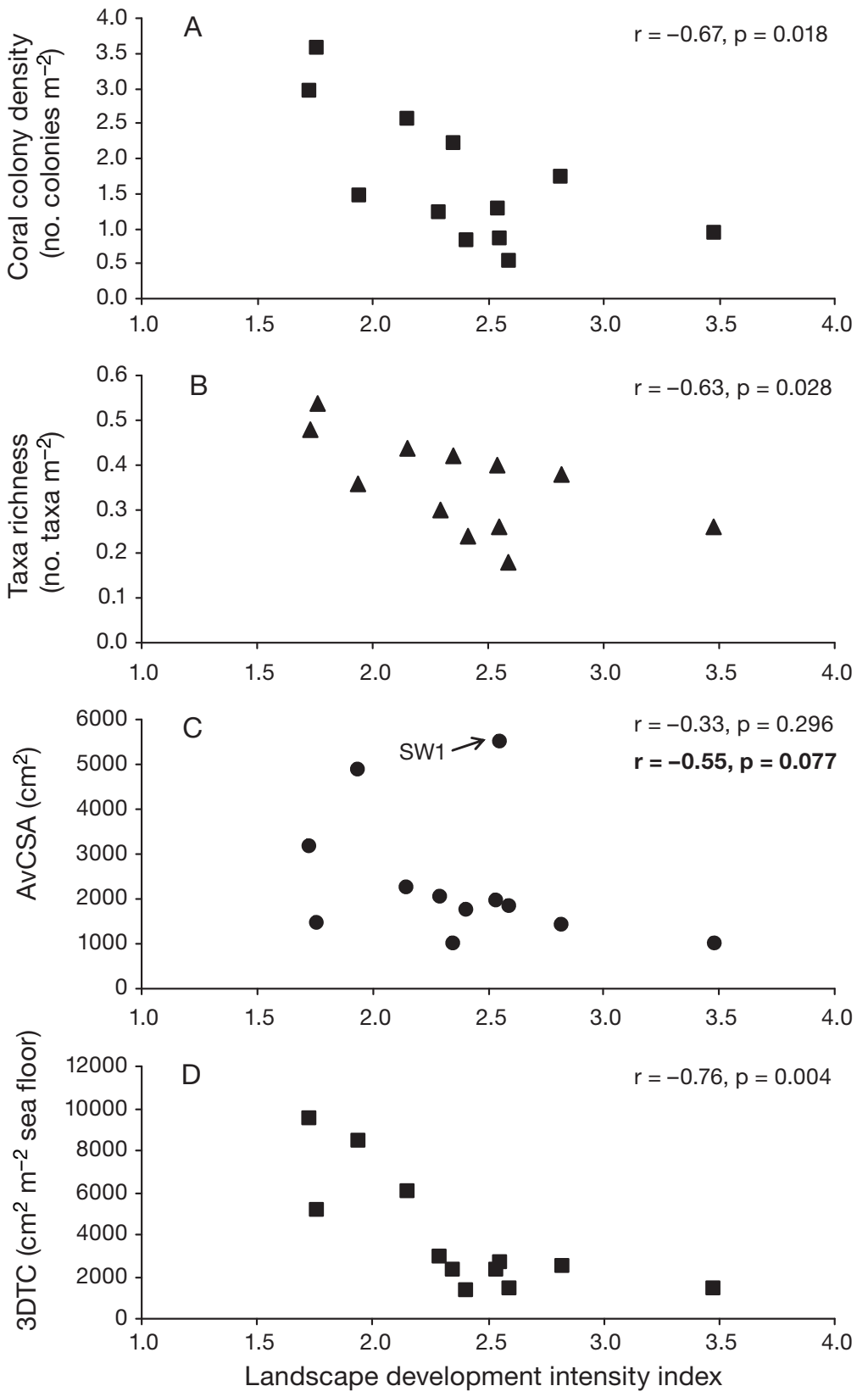

Fig. 4. Relationships between watershed landscape development intensity (LDI) values and (A) coral colony density, (B) taxa richness, (C) average colony surface area (AvCSA), and (D) 3D total coral cover (3DTC). Pearson correlation coefficients are indicated for each with accompanying p values. In (C), the coefficient in bold is the result if the outlier (SW1 marked with arrow) is excluded from the correlation analysis

cators, 2 pairs (average colony surface area and average live colony surface area; and 3D total coral cover and 3D live coral cover) were very closely correlated $(\mathrm{r}=0.70, \mathrm{p}=0.001$; and $\mathrm{r}=0.869, \mathrm{p}=0.0002$, respectively) because they are based on the same colony measurements adjusted for \% live tissue. Because of this, analysis focused on the total size metrics: average colony surface area and 3D total coral cover.
Correlations among landscape variables were examined to identify which variables were most related to the LDI values. LDI values were highly correlated with human population, percent impervious area (used in the calculation of LDI), and watershed area. High correlations were also observed between the watershed percent natural area and average elevation such that higher elevation watersheds had more natural area than low elevation watersheds.

Examination of the correlation structure of the independent variables led to the selection of 3 independent variables to be used in stepwise regression model selection procedures. The 3 variables were watershed LDI, the watershed percent natural area, and average depths of stations associated with an adjacent watershed. The LDI was selected because it was significantly correlated with many coral indicators and because the value represents an index measure of the intensity of human land use. Though the same LULC data were used to calculate both LDI and percent natural area, they were not significantly correlated because of the low LDI coefficient assigned to natural land cover classes. Consequently, the percent natural area variable was retained for the stepwise procedure. The average station depth was chosen as a variable to enter into the stepwise procedure because it was correlated with the average distance to shoreline, and to a large extent represents the degree of marine influence on the samples.

Multiple regression results (Table 4) indicated that LDI, percent natural area, and station depth were good predictors of some coral condition metrics. The LDI alone was selected as the best predictor of 3D total coral cover (Fig. 4D, $\mathrm{r}^{2}=0.58$, $\mathrm{p}=0.004$ ) and 3D live coral cover (data not shown, $\left.\mathrm{r}^{2}=0.46, \mathrm{p}=0.016\right)$. The LDI, percent natural area, and average station depth were all selected in a multiple regression model that explained $90 \%$ of the variability in the coral colony density data (Table 4). Percent natural area and average station depth were selected in a multiple regression model for taxa richness (Table 4). This model explained $74 \%$ of the variability in the taxa richness data. 
Table 4. Stepwise regression results. LDI: landscape development intensity index, B: coefficient estimate, percent natural:percent of land use classes in a watershed with LDI coefficient $=1.0$ (as shown in Table 2)

\begin{tabular}{|lcccccc|}
\hline $\begin{array}{l}\text { Condition } \\
\text { indicator }\end{array}$ & Coefficient & $\begin{array}{c}\text { Coefficient } \\
\text { value }\end{array}$ & $\begin{array}{c}\text { Coefficent } \\
\text { p-value }\end{array}$ & df & $\mathrm{R}^{2}$ & $\begin{array}{c}\text { Regression } \\
\text { p-value }\end{array}$ \\
\hline Coral density & $\mathrm{B}_{\text {LDI }}$ & -14.2 & 0.055 & 8 & 0.90 & 0.0002 \\
& $\mathrm{~B}_{\text {station depth }}$ & 4.5 & 0.036 & & & \\
& $\mathrm{~B}_{\text {percent natural }}$ & 0.9 & 0.001 & & & \\
Taxa richness & $\mathrm{B}_{0}$ & 17.2 & 0.500 & & & \\
& $\mathrm{~B}_{\text {station depth }}$ & 0.94 & 0.012 & 9 & 0.74 & 0.0020 \\
& $\mathrm{~B}_{\text {percent natural }}$ & 0.08 & 0.031 & & & \\
& $\mathrm{~B}_{0}$ & -1.12 & 0.622 & & & \\
\hline
\end{tabular}

\section{DISCUSSION}

Empirical evidence from this study supports a relationship between human activity in St. Croix watersheds and the condition of stony corals in adjacent coastal waters. Human activity, measured by the LDI index, was negatively correlated with various indicators of coral condition, including taxa richness, colony size, and colony density. In a similar study at the northern US Virgin Islands (St. Thomas and St. John), proximity to human activity was also linked to adverse change in stony coral condition using an onshore to offshore gradient (Smith et al. 2008). Together, these studies sustain the widely held belief that terrestrial anthropogenic activities adversely impact coral reefs in the near coastal zone (Loya 1976, Hubbard 1986, Richmond 1993, Miller \& Cruise 1995, Burke \& Maidens 2004, Wolanski et al. 2004, Fabricius 2005, Warne et al. 2005). It is notable that local anthropogenic effects were detected in both studies despite the many regional and global stresses, such as hurricanes (Rogers 1992, Rogers \& Beets 2001) and high-temperature events (Hoegh-Guldberg 1999, Miller et al. 2006, Rothenberger et al. 2008, Woody et al. 2008, Miller et al. 2009), which are less discriminate and could mask evidence of local stressors.

The LDI index (Brown \& Vivas 2005) integrates impacts from multiple non-renewable energy inputs to the landscape. The index increases where human activities have increased the land area of impervious surfaces, crops, pastures, houses, roads, and industrial infrastructure. The LDI has been previously shown to capture the cumulative impact of human activities in wetlands (Mack 2006, Reiss \& Brown 2007). In our study, the majority of watersheds with low LDI values and a high proportion of undeveloped lands were associated with relatively good coral condition in adjacent reefs (Figs. 2 to 4). Other landscape indicators showed significant correlations, including percentage of impervious surface which correlated negatively with 3D total coral cover. Percent impervious surface character- izes the extent of urbanization and industrial development (Grimm et al. 2008), and is highest on the south shore of St. Croix where an oil refinery, a rum distillery, and the island's international airport are located. Since heavy, intermittent precipitation in the Caribbean is common, coral reefs offshore from high impervious surface watersheds receive higher inputs of sediments and chemical contaminants, including polycyclic aromatic hydrocarbons, heavy metals, fertilizers, and pesticides (Rothenberger et al. 2008). Because percent impervious receives the highest LDI coefficient, it correlated strongly with the LDI. Nonetheless, the LDI was more sensitive, correlating negatively with multiple coral parameters.

Two other landscape indicators, percent natural land and station depth, showed positive relationships with coral colony density and taxa richness. This supports the finding that watersheds with a greater proportion of undeveloped lands are associated with healthier coral reefs, perhaps by slowing runoff rate over vegetated land. For example, northwestern St. Croix watersheds (e.g. NC2) are undeveloped, heavily vegetated, and exhibit relatively high coral condition. Significant influence of station depth is consistent with Smith et al. (2008), showing that coral reefs located away from human disturbance are more diverse and provide more reef habitat.

The finding of a negative correlation between the watershed LDI index and coral condition indicators is consistent with expectations that higher human land-use activity adversely affects coral condition. The strength and significance of the relationships from this exploratory examination reveal a strong potential for this approach to demonstrate the cumulative effect of human watershed stressors on coral reef ecosystems. Future applications would be improved by a survey design that balances the number of sites representing each watershed, incorporates landscape weighting factors for runoff potential, and better estimates coastal transport of runoff, particularly near watershed boundaries. Once refined, this tool can inform coastal management decisions that may otherwise be made solely on an economic basis. Its use should support economic development without compromising the ecological integrity of coral reefs and the services they provide.

Acknowledgements. We are grateful for technical support provided for coral surveys aboard the USEPA 'OSV Bold,' the captain and crew, and coral counters J. Campbell, D. Cooke, B. Fisher, P. Harris, B. Hemmer, A. Hutchins, M. Parsons, B. Quarles, W. Toller, and V. Vilanueva-Mayor. J. Dittmar 
assisted in GIS analysis and L. Fore provided critical data support, advice, and discussion of the concept. N. Herold provided C-CAP data updates and interpretation during NOAA C-CAP product development. Thanks to suggestions made by anonymous peer reviewers, the manuscript was greatly improved. This is Gulf Ecology Division contribution no. 1406.

\section{LITERATURE CITED}

Acala MLR, Vogt H (1997) Approximation of coral reef surfaces using standardized growth forms and video counts. Proc $8^{\text {th }}$ Int Coral Reef Symp 2:153-158

Babcock R, Smith L (2000) Effects of sedimentation on coral settlement and survivorship. Proc 9th Int Coral Reef Symp, Bali, p 245-248

Brown MT, Vivas MB (2005) Landscape development intensity index. Environ Monit Assess 101:289-309

Burke L, Maidens J (2004) Reefs at risk in the Caribbean. World Resources Institute, Washington, DC

Cortés JN, Risk MJ (1985) A reef under siltation stress: Cahuita, Costa Rica. Bull Mar Sci 36:339-356

Dahl AL (1973) Surface area in ecological analysis: quantification of benthic coral-reef algae. Mar Biol 23:239-249

> Dodge RE, Aller RC, Thomson J (1974) Coral growth related to resuspension of bottom sediments. Nature 247:574-577

Downs CA, Woodley CM, Richmond RH, Lanning LL, Owen R (2005) Shifting the paradigm of coral-reef 'health' assessment. Mar Pollut Bull 51:486-494

Dubinsky Z, Stambler N (1996) Marine pollution and coral reefs. Glob Change Biol 2:511-526

Fabricius K (2005) Effects of terrestrial runoff on the ecology of coral reefs: review and synthesis. Mar Pollut Bull 50: 125-146

Fisher WS (2007) Stony coral rapid bioassessment protocol. U.S. EPA/600/R-06/167, Washington, DC

> Fisher WS, Fore LS, Quarles RL, LoBue C, Davis WS (2008) Evaluation of stony coral indicators for coral reef management. Mar Pollut Bull 56:1737-1745

Fore LS, Karr JR, Fisher WS, Davis WS (2008) Making waves with the Clean Water Act. Science 322:1788

Fore LS, Karr JR, Fisher WS, Bradley P, Davis WS (2009) Heeding a call to action for U.S. coral reefs: the untapped potential of the Clean Water Act. Mar Pollut Bull 58: 1421-1423

> Gilmour J (1999) Experimental investigation into the effects of suspended sediment on fertilisation, larval survival and settlement in a scleractinian coral. Mar Biol 135:451-462

Grimm NB, Foster D, Groffman P, Morgan Grove J and others (2008) The changing landscape: ecosystem responses to urbanization and pollution across climatic and societal gradients. Front Ecol Environ 6:264-272

> Hoegh-Guldberg O (1999) Climate change, coral bleaching and the future of the world's coral reefs. Mar Freshw Res 50:839-866

Hoegh-Guldberg O, Mumby PJ, Hooten AJ, Steneck RS and others (2007) Coral reefs under rapid climate change and ocean acidification. Science 318:1737-1742

Hubbard DK (1986) Sedimentation as a control of reef development: St. Croix, U.S.V.I. Coral Reefs 5:117-125

> Hughes TP, Connell JH (1999) Multiple stressors on coral reefs: a long-term perspective. Limnol Oceanogr 44: 932-940

> Hughes RM, Paulsen SG, Stoddard JL (2000) EMAP-Surface Waters: a multiassemblage, probability survey of ecological integrity in the U.S.A. Hydrobiologia 422/423:429-433

Humann P, Deloach N (2002) Reef coral identification: Florida
Caribbean Bahamas. New World Publications, Jacksonville, FL

Loya Y (1976) Effects of water turbidity and sedimentation on the community structure of Puerto Rican corals. Bull Mar Sci 26:450-466

Mack JJ (2006) Landscape as a predictor of wetland condition: an evaluation of the landscape development index (LDI) with a large reference wetland dataset from Ohio. Environ Monit Assess 120:221-241

Mack JJ (2007) Developing a wetland IBI with statewide application after multiple testing iterations. Ecol Indic 7: 864-881

> Miller RL, Cruise JF (1995) Effects of suspended sediments on coral growth: evidence from remote sensing and hydrologic modeling. Remote Sens Environ 53:177-187

Miller J, Waara R, Muller E, Rogers CS (2006) Coral bleaching and disease combine to cause extensive mortality on reefs in U.S. Virgin Islands. Coral Reefs 25:418

Miller J, Muller E, Rogers C, Waara R and others (2009) Coral disease following massive bleaching in 2005 causes $60 \%$ decline in coral cover on reefs in the US Virgin Islands. Coral Reefs 28:925-937

Moberg F, Folke C (1999) Ecological goods and services of coral reef ecosystems. Ecol Econ 29:215-233

Reiss KC, Brown MT (2007) Evaluation of Florida palustrine wetlands: application of USEPA levels 1, 2, and 3 assessment methods. EcoHealth 4:206-218

Richmond RH (1993) Coral reefs: present problems and future concerns resulting from anthropogenic disturbance. Am Zool 33:524-536

Richmond RH, Rongo T, Golbuu Y, Victor S and others (2007) Watersheds and coral reefs: conservation science, policy, and implementation. Bioscience 57:598-607

> Riegl B, Branch GM (1995) Effects of sediment on the energy budgets of four scleractinian (Bourne 1900) and five alcyonacean (Lamouroux 1816) corals. J Exp Mar Biol Ecol 186:259-275

Rogers CS (1979) The effect of shading on coral reef structure and function. J Exp Mar Biol Ecol 41:269-288

Rogers CS (1990) Responses of coral reefs and reef organisms to sedimentation. Coral Reefs 62:185-202

Rogers CS (1992) A matter of scale: damage from hurricane Hugo (1989) to U.S. Virgin Islands Reefs at the colony, community, and whole reef level. Proc. 7th Int Coral Reef Symp Guam 1:127-133

Rogers CS, Beets J (2001) Degradation of marine ecosystems and decline of fishery resources in marine protected areas in the U.S. Virgin Islands. Environ Conserv 28:312-322

Rohmann SO, Hayes JJ, Newhall RC, Monaco ME, Grigg RW (2005) The area of potential shallow-water tropical and subtropical coral ecosystems in the United States. Coral Reefs 24:370-383

Rothenberger P, Blondeau J, Cox C, Curtis S and others (2008) The state of coral reef ecosystems of the U.S. Virgin Islands. In: Waddell JE, Clarke AM (eds) The state of coral reef ecosystems of the United States and Pacific Freely Associated States: 2008. NOAA Center for Coastal Monitoring and Assessment's Biogeography Team, Silver Spring, MD, p 29-73

Smith TB, Nemeth RS, Blondeau J, Calnan JM, Kadison E, Herzlieb S (2008) Assessing coral reef health across onshore to offshore stress gradients. Mar Pollut Bull 56: 1983-1991

USEPA (US Environmental Protection Agency) (2008) Handbook for developing watershed plans to restore and protect our waters. EPA 841-B-08-002. Available at www.epa. gov/owow_keep/nps/watershed_handbook/ 
Valentine JF, Heck KL Jr (2005) Perspective review of the impacts of overfishing on coral reef food web linkages. Coral Reefs 24:209-213

Warne AG, Webb RMT, Larsen MC (2005) Water, sediment, and nutrient discharge characteristics of rivers in Puerto Rico, and their potential influence on coral reefs. US Geological Survey Scientific Investigations Report 2005-2006, U.S. Geological Survey, Information Services, Denver, CO > Wilkinson CR (1996) Global change and coral reefs: impacts on reefs and human cultures. Glob Change Biol 2:547-558 Wolanski E, Richmond RH, McCook L (2004) A model of the

Submitted: June 28, 2010; Accepted: February 14, 2011 effects of land-based, human activities on the health of coral reefs in the Great Barrier Reef and in Houha Bay, Guam, Micronesia. J Mar Syst 46:133-144

Woody K, Atkinson A, Clark R, Jeffrey C and others (2008) Coral bleaching in the U.S. Virgin Islands in 2005 and 2006. In: Wilkinson C, Souter D (eds) Status of Caribbean coral reefs after bleaching and hurricanes in 2005. Global Coral Reef Monitoring Network, and Reef and Rainforest Research Center, Townsville, p 67-71

Wu W (2006) Landscape ecology, cross-disciplinarity, and sustainability science. Landsc Ecol 21:1-4

Proofs received from author(s): April 4, 2011 